\title{
The fifth culture generation of Black Sea Trout (Salmo trutta labrax): Culture characteristics, meat yield and proximate composition
}

\section{Beşinci nesil Karadeniz Alabalığı (Salmo trutta labrax): Kültür özellikleri, et verimi ve besin bileşimi}

\section{Eyüp Çakmak* (D) Ekrem Cem Çankırılıgil (D) • Osman Tolga Özel}

Central Fisheries Research Institute, Vali Adil Yazar Cad., No:14, 61250 Yomra, Trabzon-Turkey

*Corresponding author: esfcakmak@gmail.com

\section{How to cite this paper:}

Çakmak, E., Çankırrlıgil E.C. \& Özel, O.T. (2018). The fifth culture generation of Black Sea Trout (Salmo trutta labrax): Culture characteristics, meat yield and proximate composition. Ege Journal of Fisheries and Aquatic Sciences, 35(1): 103-110. doi:10.12714/egejfas.2018.35.1.16

\begin{abstract}
In this research, the culture characteristics of the fifth generation of Black Sea trout (Salmo trutta labrax PALLAS, 1814) were evaluated. First of all, trout were cultured in recirculating aquaculture system (RAS) and they kept in RAS until smoltification. After that, they were transported to marine cages till market size. Thus, the ratios of specific growth rate (SGR), feed conversion (FCR), mortality and condition factor (CF) were specified from hatching to $16^{\text {th }}$ month and the results were evaluated as pre-smoltification and after-smoltification individually. Moreover, the meat yield and proximate composition of Black Sea trout's fifth generation was specified in market size. Samplings were carried out monthly between February 2014 and May 2015. Fish were started to feed in $0.105 \pm 0.007 \mathrm{~g}$ until they reached to $335.50 \pm 44.39 \mathrm{~g}$ in May 2015. According to results; SGR, CF, FCR and mortality were determined as between 0.98-2.70, 0.86-1.15, 1.02-1.30 and 7.67$7.78 \%$ until smoltification stage, respectively. However, they were detected between $0.68-2.36,1.04-1.20,0.98-1.35$ and $0.01-5.82 \%$ after smoltification. Also, the meat yield, viserosomatic index (VSI) and hepatosomatic index (HSI) were found to be $60.30 \%, 9.28 \%$ and $1.65 \%$ in market-size respectively. According to chemical analyses, trout meat contains crude protein as $15.22 \%$, fat as $7.21 \%$, ash as $1.51 \%$ and water (moisture) as $75.17 \%$. In the view of the results, culture characteristics, proximate composition and meat yield were found similar to other cultured trout species. With these features, the fifth generation can be recommended to aquaculture sector considering the economic value of the Black Sea trout in Turkey.
\end{abstract}

Keywords: Black Sea Trout, feed conversion ratio, proximate composition, condition factor, Salmo labrax, endemic

Öz: Bu çalıșmada, Karadeniz alabalığı (Salmo trutta labrax PALLAS, 1814)'ın beșinci neslinin kültür karakteristikleri belirlenmiștir. Öncelikle alabalıklar kapalı devre yetiştiriclik ünitesi (RAS)'nde üretilmiş ve smolt boya gelene dek burada tutulmuşlardır. Sonrasında, alabalıklar deniz kafeslerine transfer edilmişler ve porsiyonluk boya gelene kadar orada tutulmuşlardır. Bu nedenle; spesifik büyüme oranı (SGR), yem dönüşüm oranı (FCR), ölüm oranı ve kondüsyon faktörü (CF) parametreleri yumurtadan çıııştan 16. aya kadar belirlenerek sonuçlar smolt öncesi ve smolt sonrası olarak verilmiştir. Ayrıca, beşinci nesil Karadeniz alabalığının

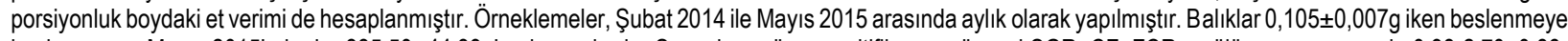

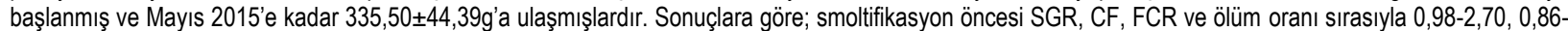
$1,15,1,02-1,30$ ve $\% 7,67-7,78$ aralıklarında belirlenmiştir. Ancak bu parametreler smoltifikasyon sonrası $0,68-2,36,1,04-1,20,0,98-1,35$ ve \%0,01-5,82 olarak belirlenmiştir. Ayrıca; pazar boydaki et verimi, viserosomatik indeks (VSI) ve hepatosomatik indeks (HSI) değerleri sırasıyla \%60,30, \%9,28 ve \%1,65 bulunmuştur. Kimyasal analizlere göre, alabalık eti \% 15,22 ham protein, $\% 7,21$ ham yağ, $\% 1,51$ ham kül ve $\% 75,17$ su (nem) içermektedir. Sonuçlar açısından, kültür özellikleri, besin bileşimi ve et verimi diğer kültüre alınan alabalık türlerine benzer bulunmuştur. Bu özellikleri ile, Karadeniz alabalığının eknomik değeri de göz önünde bulundurularak, beşinci nesil yetiştiricilik sektörüne önerilebilir.

Anahtar kelimeler: Karadeniz alabalığı, yem dönüşüm oranı, besin bileşimi, kondüsyon faktörü, Salmo labrax, endemik

\section{INTRODUCTION}

The aquaculture has increasing all over the World and culturing of new species are achieved day by day (FAO, 2017). Salmonidae species are integral part of the aquaculture sector (Emre and Kurum, 1998; Herrmann et al., 1993; Katz, 2016) with their extensive economic value (Yeakley and Hughes, 2013) and they adapted to many countries having various environmental conditions since 1970 (Knapp et al., 2007). In Europe, Atlantic salmon (Salmo salar) and rainbow trout
(Oncorhynchus mykiss) which have great importance for aquaculture sector (Alexandre and Palstra, 2017; Janssen et al., 2015; Liu et al., 2016) are cultured extensively for a long time (Elliot, 1975; Taranger et al., 2015) consisting almost 60\% of total finfish production (European Commision, 2015). Economic profitability of aquaculture and the rising importance of product varity made Salmonids as significant (Bagliniere and Maisse, 1991). For this reason, there are lots of Salmonidae 
species around the world which are cultured (Okumus, 2000).

Black Sea trout (Salmo trutta labrax) is also belongs to Salmonidae family and endemic species for eastern Black Sea (Geldiay and Balik, 1996; Innal and Erk'akan, 2006). Black Sea trout reproduce in up of the rivers where the same river they were hatched from the egg usually and they migrated to sea after smoltification for feeding parallel with growing (Geldiay and Balik, 1996; Slastenenko, 1956; Solomon, 2000; Svetovidov, 1984). This species has three ecotypes such as river, sea and lake and all of them found in Black Sea region of Turkey (Tabak et al., 2001). However, Black Sea trout is listed within important and vulnerable species by Black Sea Biodiversity and Landscape Conservation Protocol (2003). Despite the IUCN Red list (2016) state that Salmo trutta labrax not yet been assessed for their database, this species endangered according to several domestic lists (GRID, 1999; Peev et al., 2011) in Black Sea countries such as Bulgaria, Georgia and Russia. For this reason, the culture adaptation studies of this species were started by the Central Fisheries Research Institute (CFRI) from Turkey with the aim of conservation of Black Sea trout since 1998. After the success of the Black Sea trout culture, the culturing of this species has become prevalent especially in Eastern Black Sea region. Nowadays, nineteen fish farm which are registered to Republic of Turkey, Ministry of Food, Agriculture and Livestock are culture Black Sea trout legitimately and their culture reached 1440 ton per year in 2015 (TSI, 2016). Ultimately, the fifth culture line (F5) was achieved today with the works carried out such years. In this study; culture characteristics, meat yield and proximate composition of the latest culture line (fifth) of Black Sea trout were evaluated.

\section{MATERIALS AND METHODS}

\section{Fish material}

Broadstocks caught from their natural habitats which they are rivers of Firtina, Caglayan and Kapistre in northern Black Sea region in 1999 and they were adapted to culture conditions. In this study, fourth generation (F4) of Black Sea trout used as broadstocks and fifth generation (F5) which is latest culture line produced by Central Fisheries Research Institute in 2014-2015 breeding season were used in main study. The fertilised eggs of Black Sea trout are develop till 28th day, hatch in 41th day (Firidin et al., 2012) and larvae are consumes their yolc sac completely until 30th day after the hatching (Cankiriligil et al. 2016). In January, obtained larvae were started to feed and growing was started to monitoring in February 2014. Approximately 4000 larvae were used in this study. All experiments were carried out in accordance with ethical conduct amendments of ARRIVE guidelines (Kilkenny et al., 2010) and European Union Directive as 2010/63/EU (European Commission, 2010).

\section{Tank material and rearing conditions}

Main study was carried out in both recirculation aquaculture system (RAS) at around $10^{\circ} \mathrm{C}$ and marine cages within the range of $6.5^{\circ} \mathrm{C}-29{ }^{\circ} \mathrm{C}$ sea temperature and $\% 0.17$ salinity between Fabruary 2014 and May 2015. After that, the growing of larvae till smoltification were carried out in recirculating system having $1 \times 1 \times 05 \mathrm{~m}$ fiber tanks with $6.9 \mathrm{lt} / \mathrm{min}$ flow rate and $10 \%$ water exchance per day. Stock density was set as 10 $\mathrm{kg} / \mathrm{m}^{3}$ for fish until smoltification (Cakmak et al., 2010). After smoltification, fish were transported and stocked as $20 \mathrm{~kg} / \mathrm{m}^{3}$ to marine cage unit having $4 \times 4 \times 3 \mathrm{~m}$ net cages (operated in $40^{\circ} 57^{\prime} 35.07^{\prime \prime} \mathrm{N}, 39^{\circ} 51^{\prime} 21.17^{\prime \prime} \mathrm{E}$ ) in December in order to complete their life-cycle. Water temperatures were measured three times a day with thermometer in both RAS and marine cage units and were shown in Figure 1.

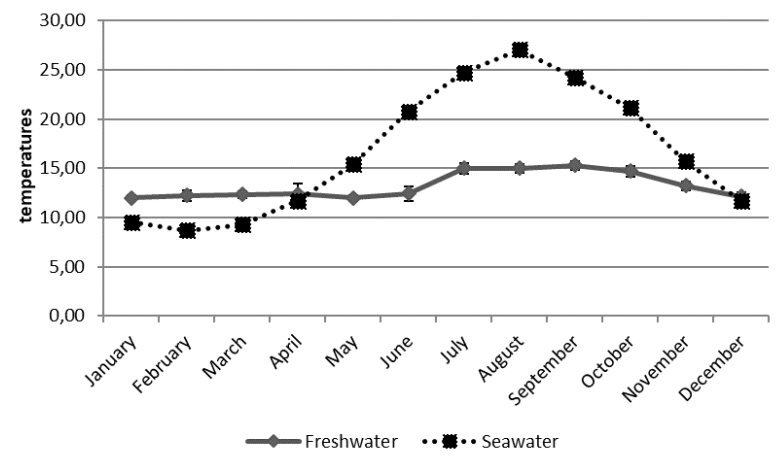

Figure 1. Yearly temperature records of freshwater re-circulating aquaculture system and marine cages. The lowest sea temperatures were recorded as $6.5^{\circ} \mathrm{C}$ in marine cages and $11.97^{\circ} \mathrm{C}$ in RAS unit. The highest tempretaures were recorded as $29^{\circ} \mathrm{C}$ in marine cages and $15.28^{\circ} \mathrm{C}$ in RAS unit.

\section{Feeding}

In the study, commercial rainbow trout feed which they are different size were used for feeding fish (Table 1). Firstly, fish were fed with daily equal to 3 percent of live fish weight and in time, this ratio was decreased to 1.5 percent parallel with fish growing. In feeding, $300-500 \mu$ granul feed was used as pregrowing feed and in time, different sized granul feed in range of $500-800 \mu$ and $6 \mathrm{~mm}$ were used respectively. Feeding was carried out 5 times per day in starting and 3 times per day in growing.

Table 1. Commerical rainbow trout feed ratio

\begin{tabular}{lcl}
\hline Composition & Pre-growing & Growing \\
\hline Protein $(\min \%)$ & 50.0 & 49.0 \\
Fat $(\min \%)$ & 15.0 & 15.0 \\
Ash $(\max \%)$ & 12.0 & 12.0 \\
Cellulose $(\max \%)$ & 2.0 & 3.0 \\
Moisture $(\max \%)$ & 12.0 & 10.0 \\
Phosphor $(\min \%)$ & 1.5 & 1.5 \\
Metabolizable energy $(\mathrm{kcal} / \mathrm{kg})$ & 4150.0 & 4000.0 \\
\hline
\end{tabular}




\section{Determination of growth characteristics}

In this study, Fulton's condition factor (CF), weight gain (WG), specific growth rate (SGR), feed conserving ratio (FCR), survival rate (SR), meat yield, hepatosomatic index (HIS) and viserosomatic index (VSI) were determined in order to determinate growth characteristics of Black Sea trout' fifth generation. The mesaurements were carried out monthly. Fish lenght measured with Von-Bayer scale and the weight was determined by using digital balance with an accuracy of $0.01 \mathrm{~g}$ (Holden and Reitt, 1974).

The equations given below were used in order to calculate these characteristics.

Fulton's condition factor (CF) (Ricker, 1975);

$C F=(W / L 3) \times 100$ W: Weight $(\mathrm{g})$, L: Lenght $(\mathrm{cm})$.

Weight gain (Ji et al., 2011);

$G R \%=[(W 2-W 1) / W 1] \times 100 \quad W_{1}$ : Starting weight (g), W2: Final weight

The specific growth (Bagenal and Tesch, 1978; Houde and Scheckter, 1981);

$S G R \%=[(\ln W 2-\ln W 1) / t] \times 100 \quad \mathrm{~W}_{1}$ : Starting weight $(\mathrm{g}), \mathrm{W}_{2}$ : final weight $(\mathrm{g})$, t: duration.

Feed conversiton ratio (Ebrahimi and Ouraji, 2012);

$F C R=F o / W g F_{0}$ : Consumed feed amount (g), Wg: Weight gain.

Survival rate (Kritsanapuntu et al., 2013);

$S R: 100 \times(n 1 / n 0) \mathrm{n}_{1}$ : Final living fish quantity, $\mathrm{n}_{0}$ starting living fish quantity.

The meat yield was calculated with edible meat after the fish filleted and seperated all organs such as gonad, digestive tract, gill and others. An equation was used to estimation of meat yield given below (Öztan, 2005). Also, viserosomatic index and hepatosomatic index were calculated according to this equation.

$$
\begin{gathered}
\text { Meat yield }=\left[\begin{array}{c}
\text { Meat weight }(g) \\
/ \text { Total weight }(g)] \times 100
\end{array}\right. \\
\text { VSI }=[\text { Viscera weight }(g) / \text { Total weight }(g)] \times 100 \\
H S I=[\text { Liver weight }(g) / \text { Total weight }(g)] \times 100
\end{gathered}
$$

\section{Proximate composition analysis}

Total moisture, crude protein, fat and ash contents were determined to identify proximate composition. In the analyses, 30 market-sized fish was used. Trout fillettes were used as whole and sectioned from three different body parts. First of all proximate composition of whole fillets were determined. Subsequently, fillets were cut into two pieces throughout from anus to dorsal, vertically. The meat tissue from anus to caudal fin named as caudal section. Second part of the fillet were also divided two pieces throughout to linea laterallis and upper part was named as dorsal, lower part was named as abdomen sections. Ultimately, Moisture content was analysed by Horwitz (2000). Samples dehydrated in drying oven at $110^{\circ} \mathrm{C}$ for 6 hours in each sample (Horwitz, 2000). Crude protein was determined by Kjeldahl (AOAC, 2000) method. In this method, the samples were digested with sulphuric acid and Kjeldahl catalyst containing selenium. Afterwards, the samples were distilled with sodium hydroxide. Further, the samples were titrated with $\mathrm{HCl}$ and obtained data were calculated by using 6.25 nitrogen conversion factor for fish and fishery products. The crude fat was specified by Folch et al. (1957). According to this method, fat content of fish meat was extracted from 5 gram of fish meat with 10 milliliter chloroform:methanol mixture (2:1) for 12 hours. The extracted samples were evaporated with a rotary evaporator at $55^{\circ} \mathrm{C}$ until the mixture was concentrated. Afterwards, Total crude ash was determined by Horwitz (2000) method. According to the method, the samples were at $600^{\circ} \mathrm{C}$ for 6 hours in burned by muffle. Ultimately, the obtained data of total fat and ash were estimated as percentages.

\section{Statistical analyses}

Differences between groups means were determined by one-way analysis of variance ANOVA using Tukey's multiple comparison tests. The level of significance was set as 0.05 (Zar, 1999). All statistics analyses were calculated using IBM SPSS Statistics package programme version 21.0

\section{RESULTS AND DISCUSSION}

The results were evaluated as pre-smolt and after-smolt along with their culture environment. In the beginning, fish mean weight determined as $0.105 \pm 0.007 \mathrm{~g}$ and they reached to smolt lenght with $12.67 \pm 0.69 \mathrm{~cm}$ length and $19.84 \pm 3.16 \mathrm{~g}$ weight in $10^{\text {th }}$ month. Cakmak et al. (2007) stated that, smoltification of Black Sea trout occurs between 11.25-11.50 $\mathrm{cm}$ and after smoltification they can adapt to marine conditions quickly same as Atlantic salmon (Salmo salar) (Davidson and Good, 2016). After smoltification, trouts were transferred to marine cages and they reached to $335.50 \pm 44.39 \mathrm{~g}$ in feeding trial ends (Table 2). The SGR were determined as highest in $4^{\text {th }}$ month with 2.70 and in $12^{\text {th }}$ month with 2.36 , lowest in $2^{\text {nd }}$ month with 1.18 and in $15^{\text {th }}$ month with 0.68 , in pre-smolt and fillet-size respectively. In smolt size, SGR was determined as 0.98 . The condition factor was calculated lowest in pre-smolth with $0.86 \pm 0.09$ and highest in after smolt with $1.20 \pm 0.10$. In smolt size, CF was calculated as $0.97 \pm 0.08$. The decrease of condition factor occurring in smolt size related to fish transporting to marine cages as well as stress caused by saltiness of Black Sea The mean of feed conversion ratio was determined as $1.10 \pm 0.12$ in pre-smolt, $1.18 \pm 0.12$ in after smolt respectively. The survival rate was determined as $93.89 \pm 3.75 \%$ in fresh water and $99.44 \pm 0.96 \%$ in marine cages. Finally, the mean weight of trout individuals calculated as $335.50 \mathrm{gr}$ as well as maximum as $347.85 \mathrm{gr}$ and minimum as $257.95 \mathrm{gr}$. Growing parameters of Black Sea trout were shown in Table 2. 
Table 2. Growing parameters of Black Sea trout alevin from hatching to 16th month beetween February 2014 and May 2015. CF: Condition factor, GR: Growth rate, SG: Spesific growth, SGR: Spesific growth rate, FI: Feed intake (biomass day \%).

\begin{tabular}{|c|c|c|c|c|c|c|c|}
\hline$n: 50$ & Lenght & Weight & CF & GR & SG & SGR & $\mathrm{FI}$ \\
\hline Feb & $2.30 \pm 0.10^{n}$ & $0.11 \pm 0.011$ & $0.86 \pm 0.09 \mathrm{~g}$ & - & - & - & - \\
\hline Mar & $2.60 \pm 0.14^{n}$ & $0.15 \pm 0.02$ & $0.88 \pm 0.06^{g}$ & 32.38 & 0.11 & 1.18 & $\% 3$ \\
\hline Apr & $3.00 \pm 0.25^{n}$ & $0.24 \pm 0.06$ & $0.88 \pm 0.09 \mathrm{~g}$ & 52.52 & 0.24 & 1.85 & $\% 3$ \\
\hline May & $3.80 \pm 0.34^{\mathrm{m}}$ & $0.50 \pm 0.13^{\prime}$ & $0.88 \pm 0.06^{g}$ & 124.53 & 0.88 & 2.70 & $\% 3$ \\
\hline Jun & $4.70 \pm 0.30^{1}$ & $1.09 \pm 0.22$ & $1.00 \pm 0.06^{f}$ & 120.38 & 1.91 & 2.17 & $\% 2.5$ \\
\hline July & $6.50 \pm 0.59 \mathrm{k}$ & $3.16 \pm 0.79^{h ı}$ & $1.13 \pm 0.08^{\mathrm{ef}}$ & 274.64 & 9.60 & 2.21 & $\% 2.5$ \\
\hline Aug & $8.10 \pm 0.69 j$ & $6,03 \pm 1.54^{\mathrm{hl}}$ & $1.11 \pm 0.07^{\mathrm{e}}$ & 28.24 & 3.70 & 2.16 & $\% 2$ \\
\hline Sep & $9.48 \pm 0.81$ & $10.04 \pm 2.70$ ghı & $1.15 \pm 0.08^{d}$ & 99.80 & 16.77 & 1.70 & $\% 2$ \\
\hline Oct & $10.80 \pm 0.75^{h}$ & $14.78 \pm 3.22^{\mathrm{gh}}$ & $1.14 \pm 0.07^{c d}$ & 33.76 & 11.33 & 1.29 & $\% 2$ \\
\hline Nov & $12.67 \pm 0.699$ & $19.84 \pm 3.16^{f g}$ & $0.97 \pm 0.08^{\mathrm{bcd}}$ & 28.66 & 12.87 & 0.98 & $\% 2$ \\
\hline $\operatorname{Dec}^{*}$ & $14.10 \pm 1.13^{f}$ & $32.1 \pm 6.228^{f}$ & $1.04 \pm 0.09 b c$ & 73.86 & 42.67 & 1.61 & $\% 1.5$ \\
\hline Jan & $17.72 \pm 1.17^{\mathrm{e}}$ & $65.33 \pm 11.05^{\mathrm{e}}$ & $1.17 \pm 0.07^{b c}$ & 119.62 & 120.13 & 2.36 & $\% 1.5$ \\
\hline Feb & $21.91 \pm 1.23^{d}$ & $124.19 \pm 23.72^{\mathrm{d}}$ & $1.17 \pm 0.08^{b c}$ & 69.99 & 154.37 & 2.14 & $\% 1.5$ \\
\hline Mar & $25.49 \pm 1.12^{c}$ & $196.63 \pm 24.71^{c}$ & $1.18 \pm 0.06^{b c}$ & 57.51 & 215.63 & 1.53 & $\% 1.5$ \\
\hline Apr & $27.20 \pm 1.34^{b}$ & $241.15 \pm 31.20^{\mathrm{b}}$ & $1.20 \pm 0.09 \mathrm{ab}$ & 25.95 & 153.27 & 0.68 & $\% 1.5$ \\
\hline May & $30.30 \pm 1.63^{a}$ & $335.50 \pm 44.39 a$ & $1.20 \pm 0.10^{\mathrm{ab}}$ & 41.46 & 308.40 & 1.10 & $\% 1.5$ \\
\hline
\end{tabular}

The first generations of Black Sea trouts (F1) which they have $2.47 \pm 0.017 \mathrm{~cm}$ length and $0.093 \pm 0.0018 \mathrm{~g}$ weight in starting were breeded for year in freshwater. According to results; trouts reached to $11.6 \pm 0.337 \mathrm{~cm}$ and $17.12 \pm 1.645$ in one year. Afterwards they transported to marine cages and they showed quick growth rates in that environment as $20.1 \pm 0.589$ $\mathrm{cm}$ and $101.77 \pm 8.957 \mathrm{~g}$ within three months. Their condition factor risen from $0.63 \pm 0.016$ to $1.04 \pm 0.010$ in end of the feeding trial. Moreover; their FCR were stated as $2.52 \pm 1.41$ and $2.83 \pm 0.70$, survival rate were stated as $90.14 \pm 12.52 \%$ and $91.85 \pm 14.30 \%$ in pre-smolt and after-smolt era, respectively (Tabak et al., 2001). Along with these, Black Sea trouts (F1) cultured in Abkhazia, Georgia reached to $20.9 \mathrm{~cm}$ length and 90.3 weight within 20 months (Solomon, 2000). In this study, the quick smoltification untill $10^{\text {th }}$ month and reaching fillet-size in $15^{\text {th }}$ month are achieved with selected breeding studies carried out since 1999 as well as decreases of mortality and feed conversion ratios in both pre-smolt and after smolt stages. According to results, condition factor was found higher to other studies carried out with first generations of Black Sea trout. The increase of condition factor in fifth generations also means to high meat yield and this condition were supported meat yield calculations. According to calculations, the meat yield of Black Sea trout's fifth genereation was calculated as $60.30 \pm 1.91 \%$ in fillet size. Atasaral Sahin et al. (2011) found meat yields raitos as $65.39 \%$ for Salmo trutta labrax, $67.28 \%$ for Salvelinus fontinalis and $69.83 \%$ for their hybrid. Also, Akhan et al. (2010) stated that meat yield of Rainbow trout that reared in Black Sea is vaired between $66.06 \pm 3.03 \%$ and $70.96 \pm 2.55 \%$. After the trouts cleaned their bones, skin and whole viscera, they lose approximately $\% 40$ lose their total weight. Some cases, the meat yield can be observed lowly by reasons of gonadal growing caused by reproduction season as well as high VSI and HSI rates caused by over-feeding of some illnesses. Thus, viserosomatic index and hepatosomatic index were found as $9.27 \pm 1.12 \%, 1.65 \pm 0.86 \%$, respectively. In the Black Sea trout's reproduction season, the size of gonads become larger until spawning and this situation meat yield are observe lowly (Cakmak et al., 2007). The reproduction season starts in November and continue to mid-january, in culture conditions (Cakmak et al., 2007). In our study, fillet-sized fish which they are not reached reproduction stage yet were used and this caused to low viserosomatic index rate as $9.27 \pm 1.12 \%$.

Uysal and Alpbaz (2002) states that, wild Abant trout (Salmo trutta abanticus) and rainbow trout (Oncorhynchus mykiss) reached from $0.088 \pm 0.01 \mathrm{~g}, \quad 0.093 \pm 0.01 \mathrm{~g}$ to $5.250 \pm 0.34 \mathrm{~g}, 133.96 \pm 9.24 \mathrm{~g}$ within 350 days, respectively. Besides that, their condition factor as $0.90 \pm 0.01,1.15 \pm 0.03$ and mortality rate as $71 \%, 35 \%$ were determined. According to another research, brook trout (Salvelinus fontinalis) which they have $6.02 \pm 1.69 \mathrm{~g}$ weight in feeding trial was started is growth to $230.28 \pm 75.73 \mathrm{~g}$ in saltwater, $318.50 \pm 99.39 \mathrm{~g}$ in freshwater. Also, feed conversion ratiso and mortality rate were determined as 1.71 and $58.5 \%$ in saltwater as well as 1.73 and $49.2 \%$ in freshwater (Okumus et al., 1998). Also, Ustaoglu and Bircan (1998) stated that rainbow trout (Oncorhynchus mykiss) breaded in marine cages has $1.92 \pm 0.11 \mathrm{FCR}, \% 17.92$ mortality and $1.38 \pm 0.04$ condition factor and they reached from $139.7 \mathrm{~g}$ to $513.5 \pm 14.93 \mathrm{~g}$ in the end of the 109 days of feeding trial. In our results, condition factor, survival rate and growth rate were found higher than the Abant trout (Salmo trutta abanticus) which is endemic species for Turkey and being cultured for the purpose of relasing to the rivers. Furthermore, while growth and mortality rates of rainbow trout cultured in freshwater which are one of the most cultured species in both fresh water and seas in Turkey (TSI, 2016) were found more than this study, condition factors were found statistically same. Our results also show that, Black Sea trout has lower growth rate and condition factor than rainbow trouts cultured in saltwater. When we compared to our results to data of other trout species cultured in Turkey, it is obvious fact that, the fifth generation of Black 
Sea trout is promising species for aquaculture sector in terms of culture characteristics.

The lifelong alterations in the growth parameters of Atlantic salmon have been determined and listed below; mean smolt length as $14.8 \mathrm{~cm}(10.5-21.5 \mathrm{~cm})$, mean smolt age as 2.91 years $(1,04-5,85)$, mean survival rate from egg to smolt as $\% 1.5(\% 0.2-3.2)$, comeback length as $56.8 \mathrm{~cm}(48.5-70.0 \mathrm{~cm})$, maturing in sea as 1.6 year(1.00-2.64) and rate of smolt to grilse as \%7.4 (\%1.3-17.5) (Hutchings and Jones, 1998). The mortality rate, specific growth rate and feed conversion rate belonging to Atlantic salmon which fed by nourishments included different levels of phospholipid, have been determined and listed as \%3.57 $\pm 0.90-\% 5.50 \pm 0.67$; (SGR) 1.34 \pm 0.14 $1.45 \pm 0.08$; (FCR) 0.76 $\pm 0.09-0.89 \pm 0.14$, respectively (Taylor et al., 2015). The individuals of Atlantic salmon have been weighted as $5,5 \mathrm{~g}$ on the average in the beginning of the experiment which nourished with products included different amounts of fish flour, wheat gluten flour and soya protein. At the end of an eighteen-week experimental period, final weight, total feed consumption and FCR values were detected and the values ranges between $19.23-27.29 \mathrm{~g} ; 35.44-40.18 \mathrm{~g} ; 1.85$ 2.63, respectively (Burr et al., 2012). Other individuals of the species which were of $31.5 \mathrm{~g}$ on the average wight in the beginning have been observed for twelve-week period in the same study. Feeding products contained fish oil, chicken flour, corn and soya proteins were used during the experiment. At the end of the period; the final weight, total feed consumption, FCR and survival rate values were measured and the values range between; 101.7-109.9, 70.0-75.9g, 0.86-0.95 and 92.4-96.3 respectively. It is highly possible to accept the potential efficiency of the Black Sea trout in the aquaculture sector due to the approximate values of breeding performance of the Rainbow trout which cultured for more than a hundred year and of the brown trout cultured worldwide. It is recommended for the administrations to separate the broodfish from the broodstock after the age of 6 in which a decreasing performance in breeding is seen, in the applications of brood management. While rainbow trout adapted itself into sea water in the month of November which has the most proper sea water temperature, Black Sea trout until the 5th generation could be grown to the size that it can hardly be adaptated to sea water in the late period. To grow the F5 Black Sea trouts, which were produced in $2014-2015$ producing period by CFRI, into smolt size will increase the profit by providing usage in advantages of sea water in producing.

According to proximate composition analysis; fifth generation of Black Sea trout meat has $75.17 \pm 1.21 \%$ moisture, $15.22 \pm 0.48 \%$ crude protein, $7.21 \pm 0.20 \%$ crude fat and $1.51 \pm 0.12 \%$ crude ash in fillet sized individuals. However, some chemical differences were observed by body parts. The meat obtained from dorsal section has highest crude protein as $16.71 \pm 0.44 \%$ and ash as $1.71 \pm 0.11 \%$, the tail section has highest ratio of water as $76.20 \pm 1.02 \%$. In abdomen, ratio of fat was determined as $10.38 \pm 0.51 \%$ and this amount is approximately two times higher than the meats sectioned from dorsal and tile sections. Proximate composition of Black Sea trout was shown in Table 3. The meat of Black Sea trout has high amount of protein, fat and ash. However, proximate composition of body parts shows differences. Abdomen section has highest fat ratio, lowest protein and moisture ratio. Contrary to this, dorsal section has highest protein and lowest fat ratios. Fish use dorsal muscles and tail for swimming and navigation. For this reason, these sections have more muscles and protein than the abdomen as might be expected (Videler, 1993; Wardle et al., 1995). The abdominal part of the muscle tissues are major fat storage sites in Salmonids (Nanton et al., 2007). Likewise, Black Sea trout is rich in terms of fatty acids (Sahin et al., 2011) and moisture and fat are exist inversely correlated in food according to Dean (1990). Also, muscles need to carbohydrates which are mostly stored in muscles in the form of glycogen (Torgersen et al., 2014) in order to compensate energy requariment for swimming (Palstra and Planas, 2011). For this reason, carbohydrate raitos were found more in dorsal and tail sections than the abdomen. Other studies that aim to evaluate proximate composition of Salmonid species in Turkey found similar results to ours. Salmo trutta macrostigma has $78.90 \pm 1.001 \%, 16.22 \pm 0.012 \%, 2.55 \pm 0.157 \%, 1.33 \pm 0.020 \%$, Salmo trutta abanticus has $78.02 \pm 0.10,18.91 \pm 0.18 \%$, $1.44 \pm 0.03,1.20 \pm 0.19$ (Uysal et al., 2002), Salmo trutta forma fario has $78.30 \pm 0.36,17.36 \pm 0.13,2.71 \pm 0.21,1.16 \pm 0.03$ (Kaya et al., 2014), Salvelinus fontinalis has $23.46 \pm 0.15 \%$, $69.51 \pm 0.37 \%, 9.92 \pm 0.07 \%, 8.05 \pm 0.18$ (dry weight basis) (Sahin et al., 2011), Oncorhynchus mykiss has $77.78 \pm 1.10 \%$, $15.47 \pm 0.21 \%, 4.11 \pm 0.55,1.94 \pm 0.04 \%$ (Çankırılıgil \& Berik, 2017) moisture, crude protein, fat and ash, respectively.

Table 3. Proximate composition of Black Sea trout's fifth generation

\begin{tabular}{|c|c|c|c|c|}
\hline$\%$ & Dorsal & Abdomen & Caudal & Whole meat \\
\hline Moisture & $75.43 \pm 1.21^{b}$ & $72.87 \pm 0.89 c$ & $76.20 \pm 0.41^{a}$ & $75.17 \pm 1.42$ \\
\hline Protein & $16.71 \pm 0.44^{a}$ & $14.49 \pm 0.24 c$ & $15.21 \pm 0.51^{b}$ & $15.22 \pm 0.48$ \\
\hline Fat & $4.71 \pm 0.52^{c}$ & $10.38 \pm 0.51^{a}$ & $6.03 \pm 0.47^{b}$ & $7.21 \pm 0.20$ \\
\hline Ash & $1.71 \pm 0.11^{\mathrm{a}}$ & $1.54 \pm 0.22^{b}$ & $1.45 \pm 0.31^{c}$ & $1.51 \pm 0.12$ \\
\hline Carbohydrate & $1.44 \pm 0.03^{a}$ & $0.72 \pm 0.01^{c}$ & $1.11 \pm 0.01^{b}$ & $0.89 \pm 0.02$ \\
\hline
\end{tabular}

Values of whole meat were not used in statistical analyses. It is fact that, best way of supplying fish source regularly and constantly to food sector is aquaculture in terms of sustainability (Anderson, 2007; Broitman et al., 2017). 
According to Teletchea and Fontaine (2014) aquaculture industry can focus on domestication of native fish species in future. Besides, $60 \%$ of European consumers like to try new fish products and species (European Commission, 2017). Thus, Black sea trout culture is becoming prevalent to aquaculture and seafood sector with all these developments. In sum, the growth performance and culture characteristics of individuals belongs to fifth culture line were evaluated in this study considering the profitable economic production models that use to culturing of Black Sea trout in Turkey. Moreover, the meat yield and proximate composition of F5 culture line were determined with the purpose of reveal that Black Sea trout as a valuable and nutricious fish species same as other prominent Salmonids. It is excpected that the study will submit further data to science community as well as becoming a source for Black Sea Trout culturing sector having a great importance for the food sector and the consumer.

\section{CONCLUSION}

Black Sea trout same as Rainbow trout are bred to a certain length in fresh water facilities and transplanted to cages in the

\section{REFERENCES}

Akhan, S., Okumus, I., Delisahasan Sonay, F., \& Kocak, N. (2010). Growth slaughter yield and proximate composition of rainbow trout (Oncorhynchus mykiss) raised under commercial farming condition in Black Sea. Kafkas. Univ. Vet. Fak. 16(Suppl-B):291-296.

Alexandre, C. M., \& Palstra, A. P. (2017). Effect of short-term regulated temperature variations on the swimming economy of Atlantic salmon smolts. Conservation Physiology, 5:1-9.

Anderson, J. L. (2007). Sustainable aquaculture: What does it mean and how do we get there? In P. Leung, C.-S. Lee, and P. J. O'Bryen (Eds.), Species and system selection for sustainable aquaculture (pp. 9-18). lowa/USA Blackwell Publishing

Atasaral Sahin, S., Bascinar, N., Kocabas, M., Tufan, B., Kose, S., \& Okumus I. (2011). Evaluation of meat yield, proximate composition and fatty acid profile of cultured brook trout (Salvelinus fontinalis Mitchill, 1814) and Black Sea trout (Salmo trutta labrax Pallas, 1811) in comparison with their hybrid. Turkish Journal of Fisheries and Aquatic Sciences 11:261-271.

AOAC. (2000). Official methods of analysis of the AOAC International., 2000 Vol. 18. The Association

Bagenal, T. B., \& Tesch, F. W. (1978). Age and growth. In: Methods for assessment Fish Production in Fresh Waters. (T. B. Bagenal, Ed.) (IBP Handbo). Oxford, UK: Blackwell Scientific Publications.

Bagliniere, J. L., \& Maisse, G. (1991). La truite biologie et ecologie. Paris France: Institut National de la Recherche Agronomique.Bilgin, Ş., Ertan, Ö. O., \& Günlü, A. (2007). The effects on chemical composition of Salmo trutta macrostigma Dumeril, 1858 of different salting techniques. E.U. Journal of Fisheries \& Aquatic Sciences, 24(3-4):225-232.

Black Sea Biodiversity and Landscape Conservation Protocol. (2003). Annex 2 List of Species of Black Sea Importance. Sofia, Bulgaria.

Broitman, B. R., Halpern, B. S., Gelcich, S., Lardies, M. A., Vargas, C. A. Vásquez-lavín, F., Widdicombe, S., \& Silvana, N. (2017). Dynamic interactions among boundries and the expansion of sustainable aquaculture. Frontiers in Marine Science, 4(15):2-5. doi:10.3389/fmars.2017.00015

Burr, G. S., Wolters, W. R., Barrows, F. T., \& Hardy, R. W. (2012). Replacing fishmeal with blends of alternative proteins on growth performance of rainbow trout (Oncorhynchus mykiss), and early or late stage juvenile Atlantic salmon (Salmo salar). Aquaculture, 334-337:110-116.
Black Sea, when the temperature of seawater is convenient. In this manner, an aquaculture model has been used which took the advantages of salt water on the trout growth in this study. Besides, Black Sea trout has high potential for aquaculture sector. In this research, culture characteristics, meat yield and proximate composition of the Black Sea Trout's (Salmo trutta labrax) fifth generation (F5) were evaluated. In a conclusion, the fifth generation can be suggested to aquaculture sector as a new culture line with their similarities other cultured Salmonid species in terms of both culture conditions and consumer interests.

\section{ACKNOWLEDGEMENT}

This research was part of "The Determination of Nutritional Requirements in Black Sea Trout (Salmo trutta labrax)" named project supported by Republic of Turkey, Ministry of Food Agriculture and Livestock. The authors would like to thank all researchers who have contributed to culturing Black Sea trout throughout the years.

Cakmak, E., Aksungur, N., Firidin, S., Cavdar, Y., Kurtoglu, I. Z., Bascinar, N. S., Akbulut, B., Savas, H., Ustundag, E., Alkan, A., Ergun, H., Erteken, A., Zengin, B., Serdar, S., Fidan, D., \& Ozkan, B. (2010). Expandability of Black Sea Trout (Salmo trutta labrax PALLAS, 1811) to Private Sector. Project Book (in Turkish).

Cakmak, E., Kurtoglu, I. Z., Cavdar, Y., Aksungur, N., Firidin, S., Bascinar, N., Aksungur, M., Esenbuga, H., Ak, O., \& Zengin, B. (2007). Karadeniz Alabalığı (Salmo trutta labrax) Yetiştiriciliği ve Balıklandırma Amacıyla Kullanımı (in Turkish). Trabzon, Turkey.

Cankiriligil, E. C., Cakmak, E., \& Ozcan Akpınar, I. (2016). Histological Development of the Digestive Tract of Black Sea Trout (Salmo trutta labrax PALLAS, 1811) During Larval Ontogeny. In 41th CIESM Congress Living Resources and Marine Ecosystems Committe (p. 330).

Çankırılıgil, E. C., \& Berik. (2017). Gökkuşağı alabalığı (Oncorhynchus mykiss) kroketlerinin soğuk muhafazada $\left(+4^{\circ} \mathrm{C}\right)$ raf ömrünün belirlenmesi. Turkish Journal of Aquatic Sciences, 5(January):35-55. doi:10.18864/tjas201704

Davidson, J., \& Good, C. (2016). A review of factors influencing maturation of Atlantic salmon Salmo salar with focus on water recirculation aquaculture system environments. Journal of the World Aquaculture Society, 47(5):605-632. doi:10.1111/jwas.12342

Dean, L. M. (1990). The seafood industry. In G. J. Martin (Ed.), Nutrition and Preparation (pp. 255-267). New York-U.S.A.: Van Nostrand Rainhold.

Ebrahimi, G., \& Ouraji, H. (2012). Growth performance and body composition of kutum fingerlings, Rutilus frisii kutum (Kamenskii 1901), in response to dietary protein levels. Turk. J. Zool, 36(4):551-558.

Elliot, J. M. (1975). The growth rate of brown trout (Salmo trutta L.) fed on maximus rations. Journal of Animal Ecology, 44:805-821.

Emre, Y., \& Kurum, V. (1998). Rainbow Trout Culture in Cage (in Turkish). (pp. 1-5). Ankara, Turkey: Minpa Publishing.

European Commision. (2010). Directive 2010/63/EU of the European Parliament and of the Council of 22 September 2010 on the protection of animals used for scientific purposes. Official Journal of the European Union, 276:1-79

European Commision. (2015). Overview report Implementation of the Rules on Finfish Aquaculture. Luxembourg: Directorare general for health and food safety, Publications Office of the European Union. doi: 10.2875/402631 
European Commission. (2017). EU consumer habits regarding fishery and aquaculture products - Special Eurobarometer 450. Directorate-Genera for Maritime Affairs and Fisheries. doi: 10.2771/443961

FAO. (2017). FAO Global Capture Production database updated to 2015 Summary information. Retrieved from http://www.fao.org/3/a-br186e.pdf

Firidin, S., Cakmak, E., \& Aksungur, N. (2012). The Black Sea Trout (Salmo trutta labrax Pallas, 1811)'s Embryonic Development Stages. Yunus Araştırma Bülteni, 2:7-16.

Folch, J., Lees, M., \& Sladane-Stanley, G. H. A. (1957). Simple method for the isolation and purification of total lipids from animal tissue. The Journal of Biological Chemistry, 226: 497-509.

Geldiay, R., \& Balik, S. (1996). Freshwater fishes of Turkey (in Turkish). Izmir Turkey: Ege University Publisher, Fisheries Faculty.

GRID. (1999). Biodiversity Report Georgia '99, Endengared Species. Retrieved February 5, 2017, from http://enrin.grida.no/biodiv/biodiv/national/georgia/State/species.htm

Herrmann, M. L., Mittelhammer, R. C., \& Lin, B. (1993). Import Demands for Norwegian Farmed Atlantic Salmon and Wild Pacific Salmon in North America, Japan and the EC. Canadian Journal of Agricultural Economics/Revue Canadienne D'agroeconomie, 41(1):111-125. doi:10.1111/j.1744-7976.1993.tb03736.x

Holden, M. J., \& Reitt, D. F. S. (1974). Methods of Resource Investigations and Their Application. In Manual Of Fisheries Science. Part 2 (p. 214). Rome Italy: FAO.

Horwitz, W. (2000). Official methods of analysis of AOAC international (Oma). Education Gaithersburg.

Houde, E. D., \& Scheckter, R. C. (1981). Growth rates, rations and cohor consumption of marine fish larvae in relation to prey concentrations. Rapports et Proces-verbaux des Reunions, Conseil International pour I' Exploration de la Mer, 178:441-53

Hutchings, J. a, \& Jones, M. E. B. (1998). Life history variation and growth rate thresholds for maturity in Atlantic salmon, Salmo salar. Canadian Journal of Fisheries and Aquatic Sciences, 55(1):22-47. doi: 10.1139/cjfas-55-S1-22

Innal, D., \& Erk'akan, F. (2006). Effects of exotic and translocated fish species in the inland waters of Turkey. Reviews in Fish Biology and Fisheries, 16(1):39-50.

IUCN. (2016). The IUCN red list of threatened species. Retrieved February 5 2017, from http://www.iucnredlist.org

Janssen, K., Chavanne, H., Berentsen, P., \& Komen, H. (2015). Rainbow trout (Oncorhynchus mykiss) - Current status of selective breeding in Europe.

Ji, H., Li, J., \& Liu, P. (2011). Regulation of Growth Performance and Lipid Metabolism by Dietary N-3 Highly Unsaturated Fatty Acids in Juvenile Grass Carp, Ctenopharyngodon idellus. Comparative Biochemistry and Physiology - Part B: Biochemistry and Molecular Biology, 159:49-56.

Katz, J. (2016). Public Goods, Regulation and the Expansion of the Natural Resource Exploitation Frontier: The Future of Salmon Farming in Chile. In A. Hosono, M. lizuka, and J. Katz (Eds.), Chile's Salmon Industry (pp. 175-193). Springer Japan.

Kaya, Y., Erdem, M. E., \& Turan. (2014). Monthly differentiation in meat yield chemical and amino acid composition of wild and cultured brown trout (Salmo trutta forma fario Linneaus, 1758). Turkish Journal of Fisheries and Aquatic Science, 14(February 2015):479-486. doi:10.4194/1303-2712-v14

Kilkenny, C., Browne, W. J., Cuthill, I. C., Emerson, M., \& Altman, D. G. (2010) Improving Bioscience Research Reporting: The ARRIVE Guidelines for Reporting Animal Research. PLoS Biology, 8(6):e1000412. doi:10.1371/journal.pbio.1000412

Knapp, G., Roheim, C. A., \& Anderson, J. L. (2007). The World Salmon Farming Industry. In The Great Salmon Run: Competition Between Wild and Farmed Salmon (pp. 57-75). Washington DC, U.S.A.: World Wildlife Fund.

Kritsanapuntu, S., Chaitanawisuti, N., \& Santaweesuk, W. (2013). Effects of dietary partial replacement of tuna oil by corn oil in formulated diets for growth performance and proximate composition of juvenile spotted babylon Babylonia areolata under hatchery conditions. Journal of Aquaculture Research and Development, 4:197-203

Liu, Y., Rosten, T. W., Henriksen, K., Hognes, E. S., Summerfelt, S., \& Vinci, B. (2016). Comparative economic performance and carbon footprint of two farming models for producing Atlantic salmon (Salmo salar): Land-based closed containment system in freshwater and open net pen in seawater. Aquacultural Engineering, 71:1-12. doi:10.1016/j.aquaeng.2016.01.001

Nanton, D. A., Vegusdal, A., Rora, A. M. B., Ruyter, B., Baeverfjord, G., \& Torstensen, B. E. (2007). Muscle lipid storage pattern, composition, and adipocyte distribution in different parts of Atlantic salmon (Salmo salar) fed fish oil and vegetable oil. Aquaculture, 265(1-4):230-243. doi:10.1016/j.aquaculture.2006.03.053

Okumus, I. (2000). Coastal aquaculture: sustainable development, resource use and integrated environmental management. Turkish Journal of Marine Sciences, 6:151-154.

Okumus, I., Bascinar, N., Alkan, M. Z., \& Kurtoglu, I. Z. (1998). Kaynak Alabalığının (Salvelinus Fontinalis) Doğu Karadeniz Koşullarında Deniz Suyu Ve Tatlısu Ortamlarındaki Büyüme Ve Kültür Potansiyeli. In III. Doğu Anadolu Su Ürünleri Symposioum. Erzurum, Turkey.

Öztan, A. (2005). Et bilimi ve teknolojisi (4th ed.). (pp. 12-13). Ankara/Turkey.

Palstra, A. P., \& Planas, J. V. (2011). Fish under exercise. Fish Physiology and Biochemistry, 37(2):259-272. doi:10.1007/s10695-011-9505-0

Peev, D., Vladimirov, V., Petrova, A. S., Anchev, M., Temniskova, D., Denchev, C. M., Ganeva, A., \& Gussev, C. (2011). Red Data Book of the Republic of Bulgaria, Volume 2 - Animals.

Ricker, W. E. (1975). Computation and Interpretation of Biological Statistics of Fish Populations. Bull. Fish. Res. Board. Can. Ottawa, Canada: Department of the Environment, Fisheries and Marine Service.

Sahin, S. A., Bascinar, N., Kocabas, M., Tufan, B., Kose, S., \& Okumus, I. (2011). Evaluation of Meat Yield, Proximate Composition and Fatty Acid Profile of Cultured Brook Trout (Salvelinus fontinalis Mitchill, 1814) and Black Sea Trout (Salmo trutta labrax Pallas, 1811) in Comparison with their Hybrid. Turkish Journal of Fisheries and Aquatic Sciences, 11(2):261-271. doi:10.4194/trjfas.2011.0211

Slastenenko, E. (1956). Karadeniz Havzası Balıkları (in Turkish). (H. E. Altan, Ed.). Istanbul: Et ve Balık Kurumu Umum Müdürlüğü.

Solomon, D. J. (2000). The biology and status of the Black Sea Salmon Salmo trutta labrax, EU Tacis Black Sea Environmental Programme.

Svetovidov, A. N. (1984). Salmonidae. In P. J. P. Whitehead, B. M. L., J.-C. Hureau, J. Nielsen, \& E. Tortonese (Eds.), Fishes of the North-Eastern Atlantic and the Mediterranean (Vol. 1, pp. 373-385). Paris, France: Unesco.

Tabak, I., Aksungur, M., Zengin, M., Yilmaz, C., Aksungur, N., Alkan, A., Zengin, B., \& Misir, M. (2001). Karadeniz Alabalığının Biyo-Ekolojik Özelliklerinin ve Kültür Imkanlarının Araştırılması (in Turkish). Trabzon, Turkey.

Taranger, G. L., Karlsen, O., Bannister, R. J., Glover, K. A., Husa, V., Karlsbakk, E., Kvamme, B. O., Boxaspen, K. K., Bjorn, P. A., Finstad, B., Madhun, A. S., Morton, H. C., \& Svasand, T. (2015). Risk assessment of the environmental impact of Norwegian Atlantic salmon farming. ICES Journal of Marine Science, 72(3):997-1021. doi:10.1093/icesjms/fsu132

Taylor, J. F., Martinez-Rubio, L., Pozo, J., Walton, J. M., Tinch, A. E., Migaud, H., \& Tocher, D. R. (2015). Influence of dietary phospholipid on early development and performance of Atlantic salmon (Salmo salar). Aquaculture, 448:262-272

Teletchea, F., \& Fontaine, P. (2014). Levels of domestication in fish: implications for the sustainable future of aquaculture. Fish and Fisheries, 15(2):181-195. doi:10.1111/faf.12006

Torgersen, J. S., Koppang, E. O., Stien, L. H., Kohler, A., Pedersen, M. E., \& Mrøkøre, T. (2014). Soft texture of Atlantic salmon fillets is associated with glycogen accumulation. PLOS ONE, 9(1):1-7. doi:10.1371/journal.pone.0085551

TSI. (2016). Turkish Statistical Institute, Fisheries Statistics 2015. Retrieved February 5, 2017, Retrieved from http://www.turkstat.gov.tr/PreTablo.do?alt id=1005 
Ustaoglu, B., \& Bircan, R. (1998). Karadeniz' deki (Sinop) Ağ Kafeslerde Yetiştirilen Gökkuşağı Alabalığının (Oncorhynchus mykiss) Büyüme ve Yem. Turkish Journal of Veterinary and Animal Sciences, 22:285-291.

Uysal, I., \& Alpbaz, A. (2002). Comparison of the Growth Performance and Mortality in Abant Trout (Salmo trutta abanticus Tortonese, 1954) and Rainbow Trout (Oncorhynchus mykiss Walbaum , 1792) under Farming Conditions. Turkish Journal of Zoology, 26:399-403.

Uysal, I., Çaklı, Ş., \& Çelik, U. (2002). Biochemical compositions of the Abant Trout (Salmo trutta abanticus T., 1954) and Rainbow trout (Oncorhynchus mykiss W., 1792) were fed with extruded pellet diet in culture conditions. E.U. Journal of Fisheries \& Aquatic Sciences, 19(3-4):447-454.Videler, J.
J. (1993). Swimming dynamics: work from muscles. In Fish swimming (pp. 139-163). Chapman and Hall.

Wardle, C. S., Videler, J. J., \& Altringham, J. D. (1995). Tuning in to fish swimming waves: Body form, swimming mode and muscle function. Journal of Experimental Biology, 198(8):1629-1636. doi:10.1006/JFBI.1993.1038

Yeakley, J. A., \& Hughes, R. M. (2013). Global and Regional Context of Salmonids and Urban Areas. In J. A. Yeakley, K. G. Maas-Hebner, and R. M. Hughes (Eds.), Wild Salmonids in the Urbanizing Pacific Northwest (pp. 11-29). New York, U.S.A.: Springer.

Zar, J. (1999). Biostatistical analysis. 4th ed. Pearson Education, India. 